\title{
Serological survey of Neospora caninum in small ruminants from Pernambuco State, Brazil
}

Inquérito sorológico de Neospora caninum em pequenos ruminantes do Estado de Pernambuco, Brasil

Antonio Amélia Santos Mucalane Tembue'; Rafael Antonio de Nascimento Ramos ${ }^{1 *}$; Thais Rabelo de Sousa²; Alessandra Ribeiro Albuquerque ${ }^{1}$; Alvimar José da Costa ${ }^{2}$; Isabelle Maria Jaqueline Meunier ${ }^{1}$; Maria Aparecida da Gloria Faustino'; Leucio Câmara Alves ${ }^{1}$

${ }^{1}$ Laboratório de Doenças Parasitárias dos Animais Domésticos, Departamento de Medicina Veterinária, Universidade Federal Rural de Pernambuco - UFRPE

${ }^{2}$ Centro de Pesquisa em Sanidade Animal - CPPAR, Universidade Estadual Paulista - UNESP

Received September 10, 2010

Accepted December 21, 2010

\begin{abstract}
Neospora caninum infection is an important cause of bovine abortion as well as neonatal mortality in goats and sheep. A serological survey for antibodies against $N$. caninum in goats and sheep was carried out in the municipality of Ibimirim, PE, Northeastern Brazil. The imunnofluoresce antibody test showed that 26.6\% (85/319) of the goats and $64.2 \%(52 / 81)$ of the sheep were positive. Serologic reactivity was associated with age in goats $(\mathrm{p}<0.01)$ and sheep ( $\mathrm{p}>0.05$ ), with increasing rates in older animals. These results indicate exposure to $N$. caninum among small ruminants in the study area.
\end{abstract}

Keywords: Coccidiosis, small ruminants, serology.

\section{Resumo}

A infecção por Neospora caninum é uma importante causa de abortos em bovinos, assim como mortalidade neonatal em caprinos e ovinos. Uma pesquisa sorológica de anticorpos anti- $N$. caninum foi realizada no município de Ibimirim (PE, Brasil). Os resultados ao teste de imunofluorescência revelaram que 26,6\% (85/319) dos caprinos e 64,2\% (52/81) dos ovinos foram positivos. A reatividade à sorologia foi associada com a idade nos caprinos $(\mathrm{p}<0,01)$ e ovinos ( $\mathrm{p}>0,05)$, com maior ocorrência nos animais mais velhos. Estes resultados indicam exposição a $N$. caninum entre pequenos ruminantes na área estudada.

Palavras-chave: Cocciodiose, pequenos ruminantes, sorologia.

Neosporosis is an important parasitic disease caused by Neospora caninum (DUBEY, 2003). Intermediate hosts of this agent in its life cycle are goats, sheep and cattle, and definitive hosts are canids (GONDIM et al., 2004).

It is a common and an important cause of abortions, endemic and epidemic, in cattle raise (ANDERSON et al., 1995), but its occurrence in goats and sheep should also be considered, and the parasite has been described associated with births of weak and premature animals (CORBELLINI et al., 2001).

Epidemiological studies carried out in different geographic regions indicate varying prevalence rates in different species, for which the main means of transmission is vertical (DUBEY,

\footnotetext{
${ }^{*}$ Corresponding author: Rafael Antonio do Nascimento Ramos

Laboratório de Doenças Parasitárias dos Animais Domésticos,

Universidade Federal Rural de Pernambuco - UFRPE,

Av. Dom Manoel de Medeiros, s/n, Dois Irmãos,

CEP 52171-900, Recife - PE, Brazil;

e-mail: rafaelanramos@yahoo.com.br
}

2003). Serological results in goats and sheep from Brazil indicate prevalence rates ranging from 9.2 to 29\% (FIGLIUOLO et al., 2004a; ROMANELLI et al., 2007).

The aim of the present study was to determine the prevalence of anti- $N$. caninum antibodies in sheep and goats in the municipality of Ibimirim in the Moxoto Semi-Arid region in the State of Pernambuco, Northeastern Brazil.

Blood samples collected from 319 goats and 81 sheep from 23 properties were studied. Owners were interviewed to obtain information regarding sex, age, management, type of system used and presence of dogs. Age was estimated through the dental arcade when unknown by the owners. Ten percent of the females from each property were studied, including those animals under one year of age, using non-probabilistic convenience methodology (COSTA NETO, 1977). All properties raised goats and sheep.

The indirect fluorescence antibody test (IFAT) was performed to detect anti- $N$. caninum antibodies based on the methods 
Table 1. Absolute and relatives frequencies of antibodies IgG anti-Neospora caninum by indirect fluorescence antibody test in goats and sheep from Ibimirim, State of Pernambuco, Northeastern Brazil, according to animal age.

\begin{tabular}{|c|c|c|c|c|c|c|c|}
\hline \multicolumn{4}{|c|}{ Goat } & \multicolumn{4}{|c|}{ Sheep } \\
\hline $\begin{array}{c}\text { Age } \\
\text { (years) }\end{array}$ & $\begin{array}{c}\text { Number of } \\
\text { animals }\end{array}$ & $\begin{array}{c}\text { Number of } \\
\text { positive }\end{array}$ & $\begin{array}{c}\text { Rate } \\
(\%)\end{array}$ & $\begin{array}{c}\text { Age } \\
\text { (years) }\end{array}$ & $\begin{array}{c}\text { Number of } \\
\text { animals }\end{array}$ & $\begin{array}{c}\text { Number of } \\
\text { positive }\end{array}$ & $\begin{array}{c}\text { Rate } \\
(\%)\end{array}$ \\
\hline$\leq 1$ & 86 & 17 & 19.8 & $\leq 1$ & 12 & 5 & 41.7 \\
\hline $1-4$ & 132 & 28 & 21.2 & $1-4$ & 49 & 31 & 63.3 \\
\hline$>4$ & 101 & 40 & 39.6 & $>4$ & 20 & 16 & 80.0 \\
\hline Total & 319 & 85 & 26.6 & Total & 81 & 52 & 64.2 \\
\hline
\end{tabular}

described by Conrad et al. (1993) and Barr et al. (1995) using conjugate anti-goat IgG (Conjugate anti-IgG goat Sigma, USA), and anti-sheep IgG (Conjugate anti-IgG-sheep Sigma, USA), with a cut-off value of 1:50 (DUBEY; LINDSAY, 1996). A reaction was considered positive when tachyzoites showed total peripheral fluorescence (PARÉ et al., 1995).

The data analysis employed the chi-square $\left(\chi^{2}\right)$ test, with the level of significance set at $5 \%(\mathrm{p}<0.05)$ to assess the association with age, sex and presence of anti- $N$. caninum antibodies.

The serological results revealed that $26.6 \%$ (85/319) of the goats were positive for anti- $N$. caninum antibodies. This rate is higher than $6.34 \%$ found by Figliuolo et al. (2004b) and 17.44\% found by Stachissini (2005), both in the State of São Paulo, Southeastern Brazil. These differences may be explained by the use of different serological tests, survey periods, sample sizes and cut-off values. Climatic factors may also affect the abundance of viable parasitic stages in the environment for definitive and intermediate hosts and influence the overall prevalence (FARIA et al., 2007).

With respect to sheep $64.2 \%$ (52/81) were positive for anti- $N$. caninum antibodies. This rate is also higher than $9.2 \%$ found by Figliuolo et al. (2004a).

According to Dubey (2003), very few studies on the prevalence of infection in small ruminants have been carried out but the reason for a higher prevalence of sheep infection may be correlated to greater susceptibility of the species (DUBEY; LINDSAY, 1996).

It is important to mention that seropositive animals did not present clinical signs suggesting neosporosis. According to Dubey and Lindsay (1996), goats inoculated with $N$. caninum develop infection, but do not develop clinical disease and only protective antibodies are observed.

Despite the higher positive results seen among females, no statistically significant difference was found regarding sex, with 10 males and 127 females positive to $N$. caninum.

Regarding age, a statistically significant difference $\left(\chi^{2}=12.82\right)$ was found $(\mathrm{p}<0.01)$ among goats, with older presenting higher rates than younger animals (Table 1 ). The same pattern was found in sheep $\left(\chi^{2}=4.83\right)$, but with no statistically significant difference $(\mathrm{p}>0.05)$ (Table 1$)$.

In the farms visited, $81.3 \%$ of them had dogs, which facilitates contamination of crops by oocysts eliminated through feces. However information regarding the serological status of the dogs was not available.

The results indicate that $N$. caninum is present in small ruminants of the study area, despite no clinical signs of the disease.

\section{References}

ANDERSON, M. L. et al. Evaluation of abortions in cattle attributable to neosporosis in selected dairy herds in California. Journal of the American Veterinary Medical Association, v. 207, n. 9, p. 1206-1210, 1995.

BARR, B. C. et al. Diagnosis of bovine fetal Neospora infection with an indirect fluorescent antibody test. Veterinary Record, v. 137, n. 24, p. 611-613, 1995.

CONRAD, P. A. et al. Detection of serum antibody responses in cattle with natural or experimental Neospora infections. Journal of the Veterinary Diagnostic Investigation, v. 5, n. 4, p. 572-578, 1993. PMid:8286457. http://dx.doi.org/10.1177/104063879300500412

CORBEllini, L. G.; COLODEL, E. M.; DRIEMEIER, D. Granulomatous encephalitis in a neurologically impaired goat kid associated with degeneration of Neospora caninum tissue cysts. Journal of Veterinary Diagnostic Investigation, v. 13, n. 5, p. 416-419, 2001. PMid:11580064. http://dx.doi.org/10.1177/104063870101300509

COSTA NETO, P. L. O. (Ed.). Estatística. São Paulo : Edgar Blücher, 1977. 264 p.

DUBEY, J. P. Review of Neospora caninum and neosporosis in animals. The Korean Journal of Parasitology, v. 41, n. 1, p. 1-16, 2003. http://dx.doi.org/10.3347/kjp.2003.41.1.1

DUBEY, J. P.; LINDSAY, D. S. A review of Neospora caninum and neosporosis. Veterinary Parasitology, v. 67, n. 1-2, p. 1-59, 1996. PMid:12666725. PMCid:2717477. http://dx.doi.org/10.1016/S03044017(96)01035-7

FARIA, E. B. et al. Prevalence of anti-Toxoplasma gondii and anti-Neospora caninum antibodies in goats slaughtered in the public slaughterhouse of Patos city, Paraiba State, Northeast region of Brazil. Veterinary Parasitology, v. 149, n. 12, p. 126-129, 2007. PMid:17706359. http://dx.doi.org/10.1016/j.vetpar.2007.07.009

FIGLIUOLO, L. P. C. et al. Prevalence of anti-Toxoplasma gondii and antiNeospora caninum antibodies in ovine from Sáo Paulo State. Veterinary Parasitology, v. 123, n. 3-4, p. 161-166, 2004a. PMid:15325042. http://dx.doi.org/10.1016/j.vetpar.2004.06.006

FIGLIUOLO, L. P. C. et al. Prevalence of anti-Toxoplasma gondii and anti-Neospora caninum antibodies in goat from São Paulo. Small Ruminant Research, v. 55, n. 1-3, p. 29-32, 2004b. http://dx.doi. org/10.1016/j.smallrumres.2003.12.013

GONDIM, L. F. P. et al. Coyotes (Canis latrans) are definitive hosts of Neospora caninum. International Journal for Parasitology, v. 34, n. 2, p. 159-161, 2004. PMid:15037103. http://dx.doi.org/10.1016/j. ijpara.2004.01.001 
PARÉ, J.; HIETALA, S. K.; THURMOND, M. C. Interpretation of an indirect fluorescent antibody test for diagnosis of Neospora sp. infection in cattle. Journal of Veterinary Diagnostic Investigation, v. 7, n. 1, p. 273-275, 1995.

ROMANELLI, P. R. et al. Prevalence of Neospora caninum and Toxoplasma gondii in sheep and dogs from Guarapuava farms, Paraná State, Brazil. Research Veterinary Science, v. 82, n. 2, p. 202-207, 2007. PMid:17266999. http://dx.doi.org/10.1016/j.rvsc.2006.04.001
STACHISSINI, A. V. M. Toxoplasma gondii e Neospora caninum em caprinos do estado de Sáo Paulo: perfis soro-epidemiológicos e co-infecçáo com o vírus da artrite-encefalite caprina. 2005. $105 \mathrm{f}$. Tese (Doutorado em Medicina Veterinária)-Universidade Estadual Paulista, Botucatu. 